\title{
Steps Toward the Establishment of a Commercial Aquaculture Insurance Program: Lessons from an Assessment of the Vietnamese Pilot Insurance Program
}

\author{
Kim Anh T. Nguyen \& Curtis M. Jolly
}

To cite this article: Kim Anh T. Nguyen \& Curtis M. Jolly (2019) Steps Toward the Establishment of a Commercial Aquaculture Insurance Program: Lessons from an Assessment of the Vietnamese Pilot Insurance Program, Reviews in Fisheries Science \& Aquaculture, 27:1, 72-87, DOI: 10.1080/23308249.2018.1481363

To link to this article: https://doi.org/10.1080/23308249.2018.1481363

Published online: 04 Oct 2018.

Submit your article to this journal $\sqsubset$

Џll Article views: 89

View Crossmark data ¿ 


\title{
Steps Toward the Establishment of a Commercial Aquaculture Insurance Program: Lessons from an Assessment of the Vietnamese Pilot Insurance Program
}

\author{
Kim Anh T. Nguyen ${ }^{a}$ and Curtis M. Jolly ${ }^{b}$ \\ ${ }^{\mathrm{a}}$ Faculty of Economics, Nha Trang University, Nha Trang, Vietnam; ${ }^{\mathrm{b}}$ Department of Agricultural Economics and Rural Sociology, \\ Auburn University, Auburn, Alabama, USA
}

\begin{abstract}
Vietnam fish producers have little adaptive financial strategies to deal with fish mortality from diseases or climatic events. Government of Vietnam (GOV) decided to implement an agriculture insurance scheme starting with a pilot program during the period 2011-2013. The objectives of the insurance pilot program were to protect rural livelihoods and to improve the efficiency of the insurance market. After the completion of the three-year pilot scheme, GOV intended to encourage the insurance companies to privatize the insurance program nationwide. The question to be asked: Was the pilot insurance well planned and are the results sufficient to encourage the private sector to commercialize the venture? The literature search showed that the aquaculture insurance program was a total disaster. The feasibility study failure was due to a lack of a prototype model for a dry run to examine the operation. There was no legal document but a set of decisions and circulars. The pilot aquaculture insurance program had only one product for the use of clients. There was an absence of a monitoring and evaluation system in place. Underwriters had no data and guide to properly evaluate claims. The heavily subsidized program encouraged price distortion, adverse selection and moral hazard.
\end{abstract}

\section{KEYWORDS}

Assessment, aquaculture, pilot, insurance, program, Vietnam

\section{Introduction}

Vietnam's agricultural program is facing a critical juncture in terms of threats to agricultural productivity from land use depletion due to climate change and crop diseases (Dang, 2015). Climate change impacts, coupled with China's water extraction upstream interfering with downstream water flow, influence not only climatic variability, but also the frequency and intensity of extreme events that harm agricultural productivity and long-term sustainable development in the Mekong delta area (Zhai and Zhuang, 2009; OECD, 2010; Hien, 2011; Khadka, 2015). According to Loc (2016) in 2013, the Mekong area was responsible for 93.2\% of the country's pangasius production area and $90.5 \%$ of its exports, more than $50 \%$ of rice area and $91.2 \%$ of its exports, $72.3 \%$ of shrimp area but $62.0 \%$ of its exports, and $36.5 \%$ of fruit area but responsible for $50.0 \%$ of exports. However, the Mekong Delta is one of the areas of Vietnam most vulnerable to climate change events (Dasgupta et al., 2007).
In spite of these environmental threats, Vietnam and the Mekong Delta have made notable progress in shrimp production and exports in the past decade (VASEP, 2016). However, fish mortality has increased due to the push to export more agricultural and aquatic products. Fish mortality has not only reduced the growth rate of fish production, but also resulted in export variation. Fish farmers have few adaptive financial strategies to deal with the problem of fish mortality from diseases or climatic events. Recent damage to the aquaculture industry from Typhoon Damrey in 2017 serves as evidence of fish farmers' dependence on government for risk management. One wonders whether a similar program as the Vietnamese government 20112013 pilot agriculture insurance program would have brought immediate relief to fish farmers who suffered damages from the recent typhoon.

The government of Vietnam (GOV) in the past used a combination of financial resources or contributions in kind to respond to the financial losses of farmers due to fish diseases and climatic events 
(Dang, 2015). Despite the fact that the GOV, the private sector, and donors absorbed some of these losses, there was still a large estimated resource gap between available financial resources and post-disaster expenditure requirements. Until 2010, instead of promoting insurance, the GOV assisted rural inhabitants and farmers who suffered losses caused by natural disasters. To assist farmers in need after a disaster, all levels of government were required to designate $2-5$ percent of their annual budgets for disaster contingency funds which were distributed to farmers as in kind payments and relief funds to cover their losses (World Bank, 2010).

The GOV decided in 2011 to implement an agriculture insurance program, starting with a pilot package during the period 2011-2013. The objectives of the pilot program were to protect rural livelihoods, to improve the efficiency of the insurance market, and to enable farmers to recover from financial losses and get back into production more quickly following natural disasters or disease outbreaks (Nguyen and Pongthanapanich, 2016). After the completion of the three-year pilot program, the GOV intended to roll out the program nationwide and allow the private sector to commercialize the insurance program.

The question to be asked: Was the pilot insurance program well planned and were the results of the operation sufficient to encourage the private sector to commercialize the venture? This paper examines the objectives, organization, and functioning of the Vietnam aquaculture insurance program. It provides an assessment of the Vietnamese pilot insurance program and discusses the factors omitted and included to determine whether its success or failure provides lessons or incentives for the establishment of a commercial aquaculture insurance venture.

\section{Overview and history of the government pilot insurance program}

In 2009, the Vietnamese Ministry of Finance (MOF) started to pilot an agricultural insurance program through desk review of legal documents, wide consultation with relevant stakeholders, and study tours to France and China with technical support from international consultants, including Swiss Re. The team that prepared the document for the pilot program evaluated the political and socioeconomic advantages of agricultural insurance and assessed the existing financial resources for disaster risk reduction in Vietnam, including the state contingency budget, flood and storm control fund, official and non-official credits, and insurance (Nguyen and Pongthanapanich, 2016). The MOF, the Ministry of Agriculture and Rural Development (MARD), and the People's Committees of the provinces/cities selected were responsible for the implementation of the pilot project (Hoang and Khoi, 2015).

The project was implemented in three sectors (crops, livestock, and aquaculture) in 20 provinces: seven provinces (comprising 481 communes) for rice crop insurance, nine provinces (180 communes) for livestock insurance, and five provinces (84 communes) for aquaculture insurance. The commodities insured were rice (under productivity index insurance) and buffalo, dairy cow, pig, poultry, pangasius, black tiger shrimp, and white-legged shrimp (under named-peril crop insurance or damage-based indemnity insurance) (Hoang and Khoi, 2015).

The pilot aquaculture insurance program was implemented in the southern provinces of Ben Tre, Soc Trang, Tra Vinh, Bac Lieu, and Ca Mau. The natural risks covered were typhoon flood, drought, cold, frost, salinity intrusion, and tsunami. The diseases covered for pangasius were liver and kidney bacterial diseases; for black tiger shrimp (Penaeus monodon), white spot syndrome, yellow head disease, infectious hypodermal and hematopoietic necrosis virus (IHHNV), and acute hepatopancreatic necrosis syndrome (AHPNS) or early mortality syndrome (EMS); and for white-legged shrimp (Litopenaeus vannamei), the same diseases covered for black tiger shrimp plus taura syndrome and infectious myonecrosis virus (IMNV) (FAO, 2016).

The GOV subsidized the premiums of participants in the pilot program by applying four levels of entitlement, as follows: $100 \%$ of the premium to poor farming households and individuals; $80 \%$ of the premium for near-poor farming households and individuals (later changed to $90 \%$ by the Prime Minister's Decision No. 358, dated 27 February 2013 (Prime Minister, 2013); $60 \%$ of the premium to normal farming households and individuals; and $20 \%$ of the premium to farming organizations and cooperatives participating in the pilot program (Nguyen and Pongthanapanich, 2016). The classifications of poverty were defined (renewed respectively) in the Prime Minister's Decision (2011) 09/QD-TTg dated 30 January 2011 on applying for poor households for the period of 2011-2015. Poor households in rural areas were those with an average monthly income of VND 400,000 or below; near-poor households in rural areas were those with an average monthly income from VND 401,000 to VND 520,000 (\$1.00 U.S. $=20,000$ 
VND). Farmers' participation in the pilot agriculture insurance program was on a voluntary basis. Of the 7487 households in five provinces that participated, 2,054 were poor (27 percent), 300 near-poor (4\%), and 5133 were non-poor (69\%). The total insured area was $5803 \mathrm{ha}$, of which $55 \%$ was in Soc Trang. The average insured area per household ranged from 0.35 to 1.05 ha (FAO, 2016).

\section{Agriculture insurance distribution network and performance}

To reach a large number of small-scale farmers in the most efficient way, the agricultural insurance program took advantage of Vietnam's existing and well-functioning rural distribution network. Farmers in each commune appointed one representative to interact with insurance companies on their behalf. On 12 September 2011, MOF issued Document 1219/BTCQLBH requesting the Provincial People's Committees to coordinate and carry out the pilot program in compliance with Decision No. 315/QD-TTg. According to this request, the chairperson of PPCs in 20 provinces/ cities were selected and their local steering committees were nominated. The steering committees at provincial, district and commune levels were established. PPCs with guidance from MOF and MARD directed and organized the program implementation with support from the People's Committees at district and commune levels (Thang, 2014; Nguyen and Pongthanapanich, 2016). The local authorities endorsed the appointment of the commune representative and he/she received all necessary support from those authorities. The representative acted in much the same way as an agent, but represented the farmers and received better support (Rogers, 2013). The farmers interested in the insurance in each commune signed up with either the commune representative or the insurance company representatives (Hoang and Khoi, 2015). This individual recorded all insurancerelevant information, such as area planted per season for rice, number of livestock per type, the aquaculture area, and volumes produced, before issuing an insurance certificate to the farmer. The insurance company issued insurance policies to the representatives, who were also responsible for collecting premiums from the farmers and distributing claim payments. Without such support from local authorities, insurance companies could not easily gain access to groups of farmers (Hoang and Khoi, 2015; Nguyen and Pongthanapanich, 2016).

The pilot program was an overall success in terms of profitability for crop and livestock insurance, but the aquaculture insurance program suffered major losses. In summary, $78 \%$ and $20 \%$ of the households engaged in crop and livestock production, but they received only 3.0 and $2.0 \%$ of the compensation, respectively (Table 1). The $2.0 \%$ of the households who engaged in aquaculture received $95 \%$ of the compensation. The conduct of a risk spread analysis conducted using the information from Table 1, shows that the spread of risks among households was much larger for crop and livestock production than aquaculture. For crop production, the risk spread (the premium divided by the number of insured households in Table 1) was VND 80,373 (USD $1 \$=22,000$ VND) per household; for livestock it was VND 216,187; but for aquaculture it was VND 89,488,446 (Nguyen and Pongthanapanich, 2016). That means the risk spread for aquaculture households was as much as 1113 and 414 times more than for crops and livestock, respectively. The burden of risk for a household in aquaculture was much more than for one in crop or livestock production. On the other hand, the premium paid per household for aquaculture was 74 and 20 times more than for crops and livestock, respectively. For the period 2011-2013, aquaculture generated all the losses. The total sum insured value was VND 2590 billion (USD 115 million). The gross premium was VND 218 billion (USD 10 million), the biggest portion of which came from Soc Trang (39\%), followed by Bac Lieu (26\%). The total claim was VND 670 billion (USD 30 million), which resulted in a loss ratio of $306 \%$ (Table 2). In addition, the average claim payment per household was considerably high for aquaculture

Table 1. Results of rice, livestock and aquaculture insurance in the pilot program, 2011-2013.

\begin{tabular}{|c|c|c|c|c|c|c|c|}
\hline Sector & Commodity & No. of households & Area (ha) & $\begin{array}{l}\text { Sum insured } \\
\text { (billionVND) }\end{array}$ & $\begin{array}{c}\text { Premium } \\
\text { (billionVND) }\end{array}$ & $\begin{array}{c}\text { Claim } \\
\text { (billion VND) }\end{array}$ & $\begin{array}{l}\text { Claim } \\
\text { ratio (\%) }\end{array}$ \\
\hline Crop & Rice & $236,397(78 \%)$ & $65,297(92 \%)$ & $2,151(28 \%)$ & $92(24 \%)$ & $19(3 \%)$ & 20.6 \\
\hline Livestock & $\begin{array}{l}\text { Buffalo, dairy } \\
\text { cow, pig, poultry }\end{array}$ & $60,133(20 \%)$ & & $2,713(35 \%)$ & $84(21 \%)$ & $13(2 \%)$ & 15.9 \\
\hline Aquaculture & $\begin{array}{l}\text { Monodon, } \\
\text { Vannamei, } \\
\text { Pangasius }\end{array}$ & $7487(2 \%)$ & $5803(8 \%)$ & $2884(37 \%)$ & $218(55 \%)$ & $670(95 \%)$ & 306 \\
\hline Total & & $304,017(100 \%)$ & $71,100(100 \%)$ & $7748(100 \%)$ & $394(100 \%)$ & 702 (100\%) & 178 \\
\hline
\end{tabular}

Source: MOF (2014) 
Table 2. Results of aquaculture insurance in the pilot program in five provinces, 2011-2013.

\begin{tabular}{|c|c|c|c|c|c|c|c|}
\hline Province & Commodity & No. of households & Area (ha) & $\begin{array}{l}\text { Sum insured } \\
\text { (billion VND) }\end{array}$ & $\begin{array}{c}\text { Premium } \\
\text { (billion VND) }\end{array}$ & Claim (billion VND) & $\begin{array}{c}\text { Claim loss } \\
\text { ratio (\%) }\end{array}$ \\
\hline Bac Lieu & $\begin{array}{l}\text { Monodon, } \\
\text { Vannamei }\end{array}$ & 1465 (19.5\%) & $1543(26.6 \%)$ & $413.766(15.9 \%)$ & $56.809(26.0 \%)$ & $188.900(28.2 \%)$ & 332 \\
\hline Ben Tre & $\begin{array}{l}\text { Monodon, } \\
\text { Vannamei, } \\
\text { Pangasius }\end{array}$ & $1718(23.0 \%)$ & 705 (12.1\%) & $487.128(18.8 \%)$ & $35.512(16.3 \%)$ & $82.100(12.3 \%)$ & 231 \\
\hline Cà Mau & $\begin{array}{l}\text { Monodon, } \\
\text { Vannamei }\end{array}$ & $811(10.8 \%)$ & $284(4.9 \%)$ & $410.325(15.8 \%)$ & $30.431(13.9 \%)$ & $100.800(15.0 \%)$ & 331 \\
\hline Soc Trang & $\begin{array}{l}\text { Monodon, } \\
\text { Vannamei }\end{array}$ & 3400 (45.5\%) & $3214(55.4 \%)$ & $1028.705(39.8 \%)$ & $85.300(39.1 \%)$ & $250.100(37.4 \%)(100 \%)$ & 293 \\
\hline Tra Vinh & $\begin{array}{l}\text { Monodon, } \\
\text { Vannamei, } \\
\text { Pangasius }\end{array}$ & $93(1.2 \%)$ & $57(1.0 \%)$ & $250.115(9.7 \%)$ & $10.200(4.7 \%)$ & $47.600(7.1 \%)$ & 467 \\
\hline Total & & 7487 & 5803 & 2590.039 & 218.252 & 669.500 & 306 \\
\hline
\end{tabular}

Source: Ministry of Finance and Provincial Steering Committees (2014).

insurance: VND 89 million (USD 3,964) (MOF, 2014; Nguyen and Pongthanapanich, 2016).

The Vietnamese government decided to stop piloting aquaculture insurance in the next phase. The heavily subsidized insurance program made it difficult to break even or to generate a profit, and resulted in market distortion and adverse selection. High-risk farmers dominated registrations for the program and encouraged moral hazard behaviors where farmers increased stocking density even though they failed to follow recommended practices (GlobalAgRisk, 2009). Farmers committed fraud by receiving compensation for claims even though they did not pay premiums and they followed no recommended practices. Other reasons for the poor performance of aquaculture insurance handled by the insurance companies included lack of a strong legal framework, lack of a central database, and weak public-private partnership (MIA, 2012).

The failure of the aquaculture insurance program can be summarized as follows:

- Widespread disease outbreaks during the implementation period (this was at a time when Early Mortality Syndrome (EMS) broke out in China, Vietnam, Thailand, and Malaysia but the causal pathogen was as yet unidentified);

- Lack of technical training for underwriters and the absence of laboratory facilities for proper diagnosis of diseases;

- Lack of adequate training for local government staff and staff of insurance companies;

- The absence of a database for analysis, monitoring, evaluation, and decision making;

- Lack of information on the size of the market area for an insurance program;

- A heavily subsidized insurance program with no information on customer willingness to pay for the insurance program;
- The application of the program over a wide fish farming area with usually small and mostly fragmented plots, which resulted in high transaction costs;

- An overly large pilot program, which made it impossible to closely monitor farmers' production process and investigate claims;

- Differences in farming practices with no recommendation in each locality;

- Low recruitment of participating farmers; and

- Lack of participation from enterprises and community-based insurance.

\section{Factors influencing success or failure}

A number of factors influence the success or failure of the aquaculture pilot insurance in Vietnam. Among the factors are the presence or absence of a legal framework, the detailed evaluation of a feasibility study, markets, technical difficulties encountered, premium acceptance, risk management, and reinsurers. All these influence the success of the insurance and discussed further.

\section{Legal framework}

The legal framework defines the rights and obligations of the parties involved in the aquaculture insurance scheme (Blommestein, 2005). One of the key concepts in insurance law is the idea of an insurable interest. The insurable interest is particularly important in stating the rules for governing and supervising the behavior of participants and investors in aquaculture insurance (Hawes, 2014). The Ministry of Finance (MOF) is responsible for supervising the insurance market in Viet Nam. The MOF has the power to grant and withdraw licenses and has authority to issue legal documents (circulars/decisions) which provide guidelines for the operation and other activities of 
insurers/reinsurers/insurance agents and insurance brokers. The Insurance Supervisory Authority (ISA), which is part of the MOF, assisted the MOF to supervise the insurance business activities and the insurance market in Vietnam. The Insurance Supervisory Authority and the MOF are the two key regulatory bodies that oversee insurance activities, including the establishment of insurers, sale and purchase of equity interests in insurance companies, the formulation, sale and implementation of insurance contracts, and other insurance-related activities (Thieu and Van, 2014).

The Vietnam insurance regulatory framework dramatically changed in 2011 when the amended law on insurance came into force. The amended law on insurance was modified for consistency with Vietnam's commitments to the World Trade Organization (WTO) and international practices. The main legislation regulating insurance business in Vietnam is the Law on Insurance Business (LIB) 2000 and its amendment in 2010, as well as guiding decrees and circulars issued by governmental authorities. They set out certain requirements for establishing and operating insurance businesses in Vietnam.

The Government decided in 2011 to implement an agriculture insurance (Decision 315/QD-TTg) during the period 2011-2013 as a further ex-ante risk management measure (IGLES, 2013). Decision 315/ QD-TTg also provided detailed guidelines and eligibility criteria for operating as an insurance provider and laid out the roles and responsibilities of ministries involved in implementing insurance programs (IGLES, 2013). After the completion of the three-year pilot program, the intention of the Government was to roll out the program nationwide. The objectives of the pilot program was to protect rural livelihoods, to improve the efficiency of the insurance market and to enable farmers to recover from financial losses (get back into production) more quickly following natural disasters and or epidemic disease outbreaks.

The GOV invited participation in the insurance scheme, but for a company to be approved by the MOF, it had to follow the guidance of the MOF and MARD and closely coordinate with local agencies, especially the People's Committees of the provinces/ cities. The Vietnam national reinsurance corporation (VINARE), and Vietnam's two largest insurers, Bao Viet and Bao Minh, were appointed by the MOF to participate in the design and implementation of the pilot program. Swiss $\mathrm{Re}$ was asked to provide technical support and reinsurance capacity. Specifically, the MOF signed Decision 2174/QD-BTC, Decision 2175/QD-BTC, and Decision 2176/QD-BTC (MOF, 2011a,2011b,2011c,2011d) allowing Bao Viet, Bao Minh, and VINARE to participate in the pilot agriculture insurance program during 2011-2013.

According to Circular No. 121/2011/TT-BTC, dated 17 August 2011, from the MOF, the insurance companies and VINARE provided agriculture insurance services in the pilot program on a "not-for-profit basis" (Article 13 of Circular No. 121). If, at the end of the pilot project, the loss from its implementation exceeded 10 percent of its equity, the MOF would have a guidance mechanism within its authority or report to the Prime Minister for consideration and support (Article 14 of Circular No. 121).

Vietnamese insurance laws and regulations are part of MARD and MOF's documents of agricultural laws and some decisions made by the prime minister's office. The questions to be asked: Are the current insurance laws and regulations adequate and sufficient for the appropriate supervision of aquaculture insurance in Vietnam? If not, can there be additional regulations and orders to the existing law? A unified legal document that defines the regulatory framework for aquaculture in Vietnam does not exist, but instead the Decisions and Circulars in which the regulatory information is scattered in diverse documents and under different ministries. This document should frame the legal policies and determine whether there are gaps in the legal system and whether these gaps can be corrected or eliminated using the current system.

\section{Feasibility study and pilot phase}

\section{The feasibility phase}

Before one can develop an aquaculture insurance pilot program, it is important to conduct a detailed feasibility study. The feasibility study is a diagnostic assessment of the status of insurance in place. The feasibility study is a critical step in the development, research, and establishment of the key parameters for the basis of the program (Blair, 2016). Country-level data collection and farmerlevel surveys may be carried out by a dedicated team appointed by the National Working Group, and technical consultants may be sourced from outside to advise and assist in the analytical process. Ideally, the local country team is advised by outside experts who can also engage in capacity building of the national team that will be involved in the program development phases. Capacity building and subsequent problem-solving ability are crucial for the long-term sustainability of any insurance program.

The purpose of the aquaculture insurance feasibility study is to generate information to enable policy 
decision makers to evaluate, analyze and determine the related risks associated with the production of various fish species. The study helps decision makers to identify information gaps in production and risk management of the fish species to be insured (Miller et al. 2002).

The team then plans a model project, making available different insurance products and options (World Bank, 2011). It is not difficult to establish a laboratory situation that can simulate a real insurance market. Hence, most insurance experiments use hypothetical situations. For example, Hill and Viceisza (2012) simulated a fertilizer purchase situation to study moral hazard in weather-index insurance, and Kunreuther and Pauly (2014) asked participants to imagine that they owned a house that was worth USD 100,000 and then make insurance purchasing decisions. Simulations are especially important when one is dealing with large numbers of limited-resource farmers. If possible, it is important to conduct a dry run on the technical elements of aquaculture insurance products, especially with index products, to ensure they focus on the most appropriate risks and are triggering the correct events. The team implements processes through the selected distribution channel, including farmer registration, premium collection/transfer to local insurance companies, policy document dispersal, claims review/loss assessment, and transfer to compensation (Blair, 2016).

In 2009, after attempts of insurance companies at offering agricultural insurance services, MOF started designing a national pilot program. The development process was mainly dependent on literature search and included a review of legal documents, consultation with stakeholders, and visits of insurance players to France and China (Nguyen and Pongthanapanich, 2016). The team concluded that agriculture insurance is necessary for Viet Nam. The team then set up a field pilot program.

\section{The pilot phase}

A pilot project is an initial small-scale implementation used to prove the viability of the project idea. This could involve the exploration of a novel approach or idea, or the application of a standard novel approach but recommended by outside parties. During the pilot project, the organizers adjust the inputs and processes to obtain the planned objectives. The pilot project enables an organization to manage the risk of a new idea and identify any deficiencies before substantial resources are committed. The risks facing producers of aquaculture products are complicated and are less well understood than those involving more traditional agricultural crops and livestock (Shaik et al., 2003). A key reason for the limited availability of aquaculture insurance is the unique set of challenges associated with implementing crop insurance programs in aquatic settings (Mahul and Stutley, 2010).

The pilot insurance program should be small enough that it allows proper monitoring. Data should be collected and adjustments made yearly to determine the best product offered to customers. Coverage should be revised annually to adjust for changes taking place. Farmers could potentially have heavy losses in one year's crop without being eligible for insurance payments (Walton and Gallons, 2005). Experience with a pilot insurance program can provide some empirical evidence about the importance of key issues of measurability, monitoring, and determination that were not considered (Beach and Viator, 2008).

A diagnosis of the Vietnamese pilot insurance program indicates the feasibility study was based on a desk study and though a review was conducted with both national and international experts, the feasibility study did not include a model showing the inputs, processes, and outputs. The opportunities and constraints of adopting certain insurance products, and cost-benefit analyses of the sale of those products were never listed (MOF. Circular No.121/2011/TTBTC dated 17 August 2011). The pilot program was too large and was not based on profit principles; hence, there were no data collected throughout the process that supplied information on project operation to intended users.

\section{Market}

Insurance is made available by the market based on economic and financial factors and associated risk levels. Of course, this comes at a price, namely an insurance premium (McIntosh, 2013). While some studies found that risk-averse farmers would have a high demand for insurance (Chantarat et. al., 2009; Kouame and Komenan, 2012), other studies found the opposite (Giné et al., 2008) or no effect (Clarke et al., 2012). Dercon et al. (2012) showed that there was an inverse relationship between price and the demand for health insurance. A number of studies on insurance demand utilize the premiums as a price measure (De Bock and Gelade, 2012). Beiner (2011) and Giesbert, et al. (2011) studied the relationship between demand for insurance and level of income. They argued that the affordability of an insurance premium is directly related to one's level of income. Studies have shown 
that people are likely to contribute to insurance coverage after a loss has occurred; this is in line with the view of accessibility preference (Johnson, et al., 1993). Du et al. (2017) empirically found that farmers revealed some aversion to incurring outof-pocket premiums in their crop insurance coverage choices. The authors suggest that farmers may be prone to a cognitive bias in assessing the benefits of insurance.

The insurance market is also guided by the financial potential of the industry and the stage of its development (Secretan, 2003). Successful insurance markets are characterized by a skewed distribution of size toward larger enterprises. The aquaculture industry in Vietnam constitutes a large number of small-scale fish farmers producing on 0.35 to 1.6 ha on average, with low levels of returns and high risks. Thus, the pilot project with farmers of low financial means could only survive with heavy GOV subsidies. Crop insurance has received government support for a variety of reasons, which may result in missing markets (Duncan and Myers, 2000), and information asymmetries (moral hazard and adverse selection problems), if present, may lead to market failure in the form of underinsurance (Nelson and Loehman, 1987; Bulut, 2017). In the case of the pilot insurance program, farmers may not have been able to clearly distinguish subsidized state welfare that was politically driven from insurance, which was a business based on a signed contract including provisions fully accepted by both parties (Chatelain, 2004).

The availability of aquaculture insurance on the market depends on underwriters making a profit from their activities (Secretan, 2003). Though there may be a healthy general market with potential underwriters willing to compete, the financial benefits and associated risks may limit coverage. Private insurance markets can be efficient in dealing with large farmers with non-systemic risk. Governments should only intervene to regulate markets to minimize imperfections and encourage participation by the private insurance and reinsurance industry (Mahul and Stutley, 2010). In the pilot insurance program, it appears GOV intervention deterred profit making and market development, since the small farmers' insurance premiums were heavily subsidized.

\section{Traditional multiple peril insurance and subsidies}

Traditional crop insurance cannot provide solutions for subsistence aquaculture farmers. There is much evidence that multiple peril crop insurance (MCI) does not work for small and marginal farmers, and usually ends up being heavily subsidized by governments (World Bank, 2012; Barnett, 2014). Individual farmer crop insurance is most effective when the farmer produces a marketable surplus and faces financial risks (FAO, 2011); in such cases the farmer is financially capable of paying the premium without a government subsidy. Most of the insurance programs in Asian countries like China, Thailand, and the Philippines are subsidized. The World Bank survey does not support the argument that premium subsidies are always a prerequisite if small-scale fish and animal producers are to purchase voluntary crop and livestock insurance, as shown by several named-peril crop insurance programs (World Bank, 2005; Roberts, 2005). Where subsidies are offered, planners should carefully identify which beneficiaries, crop or livestock sectors, and regions to target and whether the subsidies will be provided for a limited period or phased out over time once agricultural insurance takes off and achieves a critical presence in the market. Governments must carefully analyze the fiscal implications of subsidies on agricultural insurance premiums because they may not be sustainable; they can distort price signals; and they can provide inappropriate incentives to farmers.

The Vietnamese pilot insurance program registered a large number of limited-resource farmers (Thang, 2014). The farmers were never surveyed about whether they wanted to purchase insurance and the amounts they were willing to pay. The farmers who participated in the program may have exhibited moral hazard behavior where given the insurance subsidy may adopt risky practices in lieu of good agricultural practices that were not enforced with the subsidy program. One of the major problems with subsidies is that once implemented, it is difficult to remove or replace them. Farmers do not see the need for replacement, nor do governments have the political will to eliminate the subsidy program. The subsidies may encourage adverse selection where only high-risk farmers are encouraged to participate or farmers may choose periods to enter or exit the insurance industry (Pongthanapanich et al., 2016).

\section{Technical difficulties}

Fish, shellfish, and other aquatic plants and animals are produced in waters where their life support system changes constantly. Many of the perils aquaculture stock faces are a product of changing water quality and aquaculture itself. Equally, the disease risks for 
each aquaculture species are usually unknown (Roberts, 2005). Each one of these perils represents a new learning curve for the industry and its insurers. The key risks faced by aquaculture production operations include disease, infestations of parasites, cannibalism, predation, temperature fluctuations, and plankton blooms, as well as climatic events such as droughts, storms, and earthquakes, and man-made problems such as equipment and system failures, vandalism, and pollution (Secretan, 2003). Of crucial importance to the development of the aquaculture industry is the availability of support services such as disease diagnosis laboratories, fish veterinarians, and fish processing facilities, plus the ability to obtain and use drugs (Secretan, 2003). Agricultural insurance is a complex line of business that requires highly technical expertise in both the development and operational phases. Hence, there should be trained technicians and veterinarians with knowledge of aquaculture and fish diseases to perform diagnostics and provide medical services. The pilot program lacked sufficient trained workers and laboratories (Thang, 2014; Khoi et al. 2017). Disaster and epidemic risks in agriculture insurance are sometimes catastrophic, with mass destruction causing financial losses exceeding the financial capacity of the insurance companies, and therefore, claims may remain unhandled for long periods.

\section{Underwriting risks}

Agricultural insurance underwriting is used to identify individual producer risk within a region and insurance portfolio. Underwriting is also necessary for transferring risk to the reinsurers (World Bank, 2014). An underwriter is a trained individual with knowledge of the risks to which the underwritten object is exposed. This ability is gained through a mix of classroom learning and years of experience dealing with similar risks and paying claims on those risks (Macedo, 2009). Underwriting the risks of aquaculture is complicated and technically difficult to grasp. The job demands a high level of underwriting ability, training and experience in business, and fish production alongside an extensive knowledge of the aquaculture industry and its risks. The informed underwriter must understand the relationship between the proper environment and the species of fish that is being raised (IMUA, 2008). Underwriting per farm differs largely between regions, as farming systems and investments also differ largely (van Anrooy et al., 2006).
The major role played by insurance programs is the indemnification of risk-averse individuals who might be adversely affected by the occurrence of natural hazzards (Ashan et al., 1982; Raju and Chand, 2008). In the case of the pilot aquaculture program, there were only a few business-trained underwriters with limited knowledge of the aquaculture industry. There were not many individuals with the required experience, and there were no training facilities to teach skills to new underwriters. The technicians who evaluated the risks were unable to identify the claims associated with certain perils and hence could not give proper estimates of the degree of loss (Thang, 2014).

The insurance products offered should be based on the farmers' preferences and their utility-maximizing behavior (Secretan, 2003). This means that the expected utility ranking is always higher for risky choices with higher mean returns (Brennan, 2002). The underwriter's interest is in low risk and high returns in favor of the insurance company. In conventional insurance, the basic issue to be addressed is whether the insurance is meant to substitute for farm income in the event of a loss event, or merely cover the cost of inputs lost because of mortality (Roberts, 2005). Should the packages relate to the peril in terms of costs, profits, or expected returns? Should it be more on investment costs or fixed costs? The selected insurance for the pilot program was based on the stated loss on a cost basis. However, the underwriters lacked the information to determine the investment costs to make the right decisions for claim settlement.

The participants in the pilot program were not required to follow any recommended practices. Industry results show that the government decree only required the adoption of VietGAP or GlobalGAP by 2015 (Lutz, 2015; Nguyen and Jolly, 2017). Since there were no recommended practices, the underwriters were not sure what to examine and to measure. To reduce the liability exposure of the farms, efforts should have been made to monitor and patrol farms regularly to check for disease incidence. Serious attention should have been paid to special areas of the venture, such as water quality and the incidence of pollution from water sources and other neighboring industries. Underwriters must pay constant attention to the quality of the risks being offered to them, and also be sure that the husbandry standards in the production units they are covering are constantly maintained (FAO, 2007a). Additionally, new risks they are offered have to be assessed and rated, but only 
after full information has been gathered on them (FAO, 2007b).

To meet these standards, farmers must collect data on their crops and production systems, and there must be a way of validating such records (Epetimehin, 2011). Such data are prerequisites for insurance coverage. Coverage and expected indemnity are essential features of crop insurance (Coble and Barnett, 2008). Coverage determines the share of the loss that is covered by the insurer, while the deductible is the share covered by the farmer. The reimbursement of indemnities in the case of crop failure enables the farmers to repay debts, and thus, their credit with formal financial institutions is maintained intact (Hazell et al., 1986; Pomareda, 1986; Mishra, 1996).

The pilot insurance market imposed production and monitoring requirements with which the farmers were not familiar, and therefore, increased their costs. "The stringent standards demanded by aquaculture insurance markets, the high costs of meeting them and high underwriting costs work directly against small, individual, household-based aquaculture farmers obtaining insurance; they are too small scale to collect meaningful and detailed data and at the same time generate significant premium. These marginal farms are quickly viewed by adjusters as the ones likely to produce high levels of losses that are expensive to adjust and pay" (FAO, 2007b; Nguyen and Pongthanapanich, 2016). The pilot program attempted in Vietnam provided underwriting challenges, since there was insufficient information on production systems and losses to make quick adjustments and settle insurance claims. As noted in Table 2, the claim loss ratios were extremely high and varied from 2.32 to 4.67 .

\section{Acceptability of premium levels and terms and conditions}

The "availability" of any product or service is influenced by its price. If a service is too cheap, the providers cannot profit by making it available; on the other hand, if it is too expensive, end users will not buy it (IGES, 2013). Aquaculture insurance appears to be in such a predicament. There appears to be considerable resistance to buying insurance among fish farmers, at least some of whom consider premiums to be too expensive; furthermore, underwriters for the pilot insurance program were not concerned about making profits to show that the program could operate as a business (Secretan, 2003). The results of the pilot program showed that shrimp farmers had a relatively high willingness to pay for insurance, since they are generally risk averse and acknowledge the risk involved in shrimp farming (Hadnes and Czura, 2014). In Vietnam, farmers are not only risk averse, but fear that if they speak of losses, they will suffer from eventual disaster. The farmers are more likely to accept varied levels of payments for losses suffered along the production calendar in terms of number of days after stocking. In general, farmers would prefer higher compensation rates in earlier stages of crop failure than in later stages, when the risk of crop failure is lower and they have the chance to sell their harvest (Hadnes and Czura, 2014). The administrators of the pilot program were not sure about the number of days to insure against the named perils and whether the period should be based on operating, fixed costs, or profit. Further, the recommendation was the coverage of costs of pond rehabilitation for farmers who had experienced crop failure (Hadnes and Czura, 2014).

\section{Risk management}

General risk spreading techniques in the market are diverse and depend greatly on the size and extent of the business requiring cover. An individual shares a given risk with an insurance company; the individual is assumed to be risk averse, whereas the insurance company is assumed to be risk neutral (Reddy, 2004). Risk pooling refers to a situation where persons with different risks place their risks in a common shared pool; for example, insurance is provided collectively to a group consisting of members who may face different probability distributions of loss (Reddy, 2004). Risk spreading involves shifting the risks from an individual or corporation that is unable to bear the risks to third parties with the capability of absorbing the risks. The major aquaculture producers, given the size, diversity, and geographical distribution of their production sites, tend to seek differently structured insurance protection than smaller producers do. The best time to take action is early on, before a situation gets too bad; however, aquaculture insurance policies should also contain high deductibles (up to 10 percent, 20 percent, or 30 percent of a whole site, or even larger), and with such high deductibles, a relatively insignificant situation can develop and degenerate quickly into something much worse (Secretan, 2003). Most of the pilot program participants did not understand the process of risk sharing and why there should be a deductible. They were mainly interested in the premium and the indemnity payments. 
Managing risk effectively requires that one identifies the risks that one is likely to face (McIntosh, 2013). It involves anticipating outcomes and planning a strategy in advance given the likelihood and consequences of events, not just reacting to those events after they occur (Hardaker, et al., 1997). Typically, aquaculture insurance programs are intended to transfer risk from one party to another, generally away from the producer and to the insurance underwriter or other corporations. The farmer then uses different risk management approaches for risk spreading, which affect the net returns of producers (Velandia et al., 2009). The study by Velandia et al. identified the proportion of owned acres, off-farm income levels, education, age, and level of business risk as factors that determine adoption of crop insurance and other risk management tools. New risk management tools such as using risk-reducing inputs like irrigation, forward pricing, savings, maintaining credit reserves, more adapted seeds, better flood prevention devices, better advisory services, or ex-post banking and credit systems are powerful instruments to manage risks in aquaculture (World Bank, 2008; Barnett and Coble, 2008).

Risk assessment is essential to quantify the value of each potential risk and determine the likelihood that it will occur (Power, 2004). Aquaculture insurance is also used as a tool to increase cooperation between various aquaculture sector stakeholders (aquaculture entrepreneurs, financial institutions, and government agencies), with the overall goal of reducing risks in both aquaculture production and the insurance service. Aquaculture insurance schemes are, therefore, generally designed to promote "good" behavior: that is, aquaculturists should try to minimize the risks involved for themselves, the environment, and their insurance companies (van Anrooy et al., 2006). Risk management in the pilot program was not evident, since there was no need if one was compensated for losses when there was no tracking of risk incidence. There also should be advocacy for credit and banking services to accompany insurance programs for limited-resource farmers, which was absent in the development of the pilot program.

\section{Reinsurers}

Reinsurance is an insurance for insurers. Reinsurance transfers both risk and premium to other insurers and provides diversification of risks and substitutes for equity or debt (Goodwin, 2013). The reinsurer agrees to indemnify all the losses of the insurance companies it serves (Swiss Re, 2004). The international aquaculture market is dominated by a small number of international reinsurers (Macedo, 2009), including Swiss Re and Munich Re, and to a lesser extent SCOR, Hannover Re, Partner Re, Sunderland Marine, and various syndicates at Lloyd's. In well-established aquaculture insurance markets such as Chile, Norway, Scotland, and Canada, and in parts of Asia, these reinsurers are willing to grant treaty reinsurance capacity to local insurers. However, most of the international insurance and reinsurance market for aquaculture is placed on a facultative or case-by-case basis and is subject to pre-inspections and risk surveys by international aquaculture specialists. Also, reinsurers usually insist on appointing their own independent loss adjusters to attend and assess losses. Because the risks are high in operating an insurance business, insurance companies need to be backed by reinsurance. However, the reinsurance market in Vietnam was undeveloped and there was no reinsurance program sharing the risks of the primary insurers (IGES, 2013). The Vietnam national reinsurance corporation (VINARE) was supposed to participate in the reinsurance program, but on a nonprofit basis. The reinsurance companies had no incentive to reinsure the other companies, and there is no information on how this aspect of the project worked.

\section{Compulsory versus voluntary}

Governments often seek to make agricultural insurance compulsory, particularly where farmers are heavily subsidized and borrow credit from national agricultural development banks. From a farmer's viewpoint, compulsory agricultural insurance may be very unattractive, unless it is accompanied by premium subsidies and/or farmers are able to gain access to bank credit that they would not otherwise have been eligible for, and which is sometimes provided at concessionary interest rates. From an insurer's perspective, there are two potential benefits of compulsory insurance: (a) the reduction of adverse selection, which is a major problem in voluntary agricultural insurance programs; and (b) the ability to generate a larger and more balanced agricultural insurance portfolio. Compulsory insurance is sometimes viewed as the response to adverse selection (Mahul and Stutley, 2010). The costs to the insurer of farmer awareness and promotional campaigns are also considerably lower where agricultural insurance is marketed on a compulsory basis (FAO, 2011). Chiappori and Salanie (2000), Cardon and Hendel 
(2001), Kolstad and Kowalski (2016) used empirical evidence to test the adverse selection model, and found adverse selection in the voluntary (private insurance) market. In contrast, in the case of compulsory insurance, there was no adverse selection, as it forces all individuals, including risk averters and risk lovers, into the consumer pool.

There are potential benefits for lending institutions to transfer farmers' default risk as a result of adverse natural and weather events to the insurance industry, thus increasing the farmers' creditworthiness (Roberts, 2007; FAO, 2011). Distorted insurance premium rates induce high-risk but not low-risk farmers to purchase insurance. Makki and Somwaru (2001) found evidence of adverse selection in both coverage level and insurance type decisions. High-risk producers were more likely to select revenue insurance contracts and higher coverage levels. The performance of the insurance program deteriorates as lower-risk farmers stay out of or leave the program, leading to its collapse. The appropriate response to the problem of adverse selection is through an actuarially sound insurance program based on risk discrimination.

Compulsory insurance ensures that low-risk farmers participate in the program, forcing them to cross-subsidize high-risk farmers, thereby ensuring the viability of the program. However, this artificial viability may be socially suboptimal, as the aggregate loss of welfare of the low-risk farmers may exceed the aggregate welfare surplus of the high-risk farmers. Just, et al. (1999) found that the subsidy benefits of crop insurance outweighed its risk-aversion incentive and were largely due to adverse selection. Compulsory insurance is sometimes invoked when a minimum participation is required to pool risks and cover fixed costs. The economic rationale of the pooling argument is somewhat questionable, because the basic concept of pooling relies on a group of homogeneous risks in which all participating agents benefit from risk pooling. Compulsory insurance forces low-risk agents to participate in a scheme based on a wealth transfer, not a risk-pooling mechanism (Mahul and Stutley, 2010).

The pilot insurance program in Vietnam was voluntary even though it was heavily subsidized. The objective was to politically assist farmers to improve their welfare. A large number of farmers who participated considered themselves poor, even though the data for poverty establishment were not reliable. The farmers who were financially better off preferred not to bother with the insurance coverage and left it mainly to those considering themselves extremely poor.

\section{Conclusions}

The pilot insurance program was organized after a feasibility study conducted by national and international experts. The experts conducted literature reviews as well as site visits to other countries. The failure of the feasibility study to serve as a guide to the success of the pilot program was due to the lack of a prototype model to be used in a dry run to examine the processes, inputs, outputs and the degree of financial success. Only a set of decisions and circulars governed the establishment and operation of the pilot program, it seemed to be hurriedly organized, and it had only one product for clients. The clients had very few alternative products from which to choose. There was no monitoring and evaluation system in place to record the business activities and behaviors of the clients.

The objective of the program was to assist the rural poor to improve their welfare. There were many poor individuals (27\%) registered who received 100 percent subsidy. Hence, there was little chance of the program generating any profit. The administrators requested that the insurance companies and the reinsurers participate on a nonprofit basis, yet expected them to take over the insurance program at the end of the trial period. This is a mixed signal, and there is no insurance group that would be ready to take on this burden created by the government. Another major problem was the lack of awareness created by the pilot program, in that the participants did not know the difference between a state welfare program and an insurance program.

The heavily subsidized insurance program made it difficult to break even or to generate a profit. The subsidized program resulted in market distortion and adverse selection. High-risk farmers dominated the program and encouraged moral hazard behaviors. Farmers received compensation for claims even though they did not pay premiums and they followed no recommended practices. The underwriters, though they were trained in business management, knew little about the aquaculture industry (Thang, 2014). The farmers were never questioned about their willingness to pay for aquaculture insurance or the amounts and types of products needed. There was one product across the board for all farmers, even though agricultural insurance programs need to be customized to beneficiaries.

The emerging commercial agricultural sector in Vietnam needs more standardized insurance products offered through cooperatives or rural finance institutions, such as credit-linked agricultural insurance 
(Mahul and Stutley, 2010). The traditional farming sector may not be geared toward commercial insurance; government may therefore need to consider alternative support mechanisms, in the form of social safety net schemes, for the poorest farmers and a pooled or mutual insurance program for those who can afford.

A pilot project represents a small-scale model of the idea to be implemented. If the idea is a project that is profit seeking, the objective of the pilot project should be producing positive net returns above costs. The net returns should encourage the project administrators to scale up the pilot project based on expected financial success. The GOV expected that the private sector would pick up the pilot insurance project if it demonstrated potential profit generation. Unfortunately, the objectives of the pilot program, as stated above, were selected more to enhance social welfare and reduce participants' losses (Nguyen and Pongthanapanich, 2016). In fact, the MOF requested that the insurance companies and VINARE provide agriculture insurance services in the pilot program on a "not-for-profit basis." Then the question is, if there was no profit, why would the insurance companies participate in scaling up the project?

Lessons learned

- The pilot project was not based on research or on prototype models for the generation of information on product risks. The pilot insurance program was based on a desk study and knowledge received by planners from visits to neighboring countries. There was no prototype models or studies on the willingness to pay for insurance and data collected on insured households' behavior that could be used for the modification of proposals and guidelines for a future phase. The pilot program was large and lacked a component for monitoring and evaluation.

- Subsidies were given to large numbers of households without any guarantee that the poorer households were the ones benefiting from the subsidized premiums. There was no study on the levels of subsidy that could encourage participation by a large number of farmers of varying farm incomes.

- The insurance companies were not well informed of the regulations for underwriting and they lacked information on recommended practices that the farmers should follow. Farmers were not required to follow any recommended technology packages to participate in the insurance program.

- There was an absence of specific rules for the determination of premium, loss insured and procedure for compensation that could have facilitated the task of the underwriters.

- The contract developed between the insured and the insurer was not transparent and details on each party responsibility was not clear.

- There are not many successful pilot aquaculture program in existence from which information can be sourced. Hence, this insurance program could not depend on following the methods and procedures of operation from outside sources. Hence, the pilot aquaculture program required time for planning and execution.

- Aquaculture insurance is a new and complex field; the professional requirements for the technical-scientific aspects of aquaculture insurance operations are immense. Therefore, aquaculture insurance officers should be technically trained in aquaculture and insurance to provide adequate response to rural household insurance needs.

- The cost of data collection for small limited resource farmers can be prohibitive and procedures for data collection had to be well panned. The improvement of collection and management for enhancing communication between farmers and inures was rendered difficult

- The high government subsidy prevented the participation of business entities in the pilot insurance program and made it difficult for the private enterprise to decide to undertake the pilot program as a business venture given that the large subsidies may have encouraged adverse selection.

\section{Recommended practices}

Often, agricultural insurance is misunderstood as a panacea for risk management and climate adaptation. However, as Warner et al. (2009) point out, insurance will fail to reduce risk and to advance adaptation unless it is implemented along with risk management and disaster risk reduction measures. All fish farmers in Vietnam should be requested to follow Viet GAP or Global GAP to participate in an insurance program. The insurance program can either stand as an aquaculture insurance program or an insurance program that covers a number of species and agricultural crops. It could be either a stand-alone entity or hosted by a pool of insurers such as VINARE, Bao Viet or Bao Minh and other financial institutions that are willing to provide insurance services. It can also include the participation of processors exporters and participants all along the value chain. The program 
should have a technical support unit with the following goals:

- MOF in conjunction with MARD can create a center of expertise able to support the development of a prototype pilot insurance model and the scaling-up of the agricultural insurance program based on the results of the pilot program.

- Establish a core team of agricultural insurance experts from MOF and MARD to provide technical support and training to agricultural insurers in underwriting, product development, pricing, product delivery, loss adjustment, catastrophe risk financing, and monitoring and evaluation.

- Select a group of farmers who are willing to participate in or pay for an insurance program, and have them participate in a profit-generating program, even though part of the administrative cost is subsidized. It is important to consider subsidizing administrative costs because of the smallness of the program under study.

- Adopt a named-peril such as disease infestation, storms or typhoons for which the insurance can be purchased. The selection of two species will facilitate the collection of data for the monitoring and evaluation of the pilot program.

- Put in place a document that outlines the establishment of the pilot insurance program with a set of guidelines for its operation and recommended practices based on VietGAP or GlobalGAP that insurance providers and farmers can follow. This document should include a section on the way forward at the end of the pilot program.

- Set up laboratory systems at optimal distributed locations in the selected provinces where the pilot program will be established for the training of technicians and the testing of fish disease and water samples.

- Create and manage a centralized database of aquaculture production systems, farm income and expenditures, disease outbreaks and treatments, and weather statistics, and make the database available to agricultural insurance practitioners and farmers alike.

- Tie the database to the monitoring and evaluation system and use the database in underwriting and training of technical specialists in field decision making.

- Promote close collaboration with key stakeholders such as insurance companies, banks, and credit systems for their participation.

- Conduct a pilot program for three years and then invite insurers and reinsurers to participate in the program.

\section{Acknowledgments}

The authors would like to thank ClimeFish and NORHED projects for their assistance in preparing this paper.

\section{References}

Ashan, S. M., A. A. G. Ali, and N. J. Kurian. Towards a theory of agricultural crop insurance. Am. J. Agric. Econ., 64(3): 520-529 (1982).

Barnett, B. Multiple-peril crop insurance: Successes and challenges. Agric. Fin. Rev., 74:200-216 (2014).

Barnett, B. J., and K. H. Coble. Are our agricultural risk management tools adequate for a new era? Choices. Available from http://www.choicesmagazine.org/magazine/article.php?article $=62$ (2008).

Beach, R. H., and C. L. Viator. The economics of aquaculture insurance: An overview of the U.S. pilot insurance program for cultivated clams. IAAEM, 12:25-38 (2008).

Beiner, C. Pricing in Microinsurance Markets (Working Papers on Risk Management and Insurance No. 106). St. Gallen, Switzerland: Institute of Insurance Economics, University of St. Galle (2011).

Blair, L.A. 10 Phases in Developing a National Crop Insurance Program: An Overview. Ho Chi Minh City, Vietnam: ASEAN Climate Resilience Network (ASEANCRN) (2016).

Blommestein, H. Legal and regulatory framework for developing government bond markets - Suggested issues for discussion. Second OECD-China Forum on Public Debt Management and Government Securities Markets. Paris: OECD. (2005).

Brennan, D. Savings and technology choice for risk averse farmers. AJARE, 46(4): 501-513 (2002).

Bulut, H. Managing catastrophic risk in agriculture through ex ante subsidized insurance or ex post disaster aid. JARE, 42(3): 406-426 (2017).

Cardon, J. H., and I. Hendel. Asymmetric information in health insurance: evidence from the national medical expenditure survey. RAND J. Econom., 32(3): 408-427 (2001).

Chantarat, W., A. G. Mude, and C. B., Barrett Willingness to pay for in-dex based livestock insurance: Results from a field experiment in Northern Kenya. Working Paper. Ithaca, NY: Cornell University (2009).

Chatelain, N. S. Challenges in implementing agricultural insurance and reinsurance in developing countries. In: Paper presented by ICDC; General Liability \& Agri. Risk Manager, SCOR Group Paris. The journal; 65-69 (2004).

Chiappori, P. A., and B. Salanie. Testing for asymmetric information in insurance markets. J. Pol. Econ. 108(1): 56-78 (2000).

Clarke, D. J., O. Mahul, K. N. Rao, and N. Verma. Weather Based Crop Insurance in India. The World Bank (2012).

Coble, K., and Barnett, B.. Implications of integrated commodity programs and crop insurance. J. Agric.Appl. Econ., 40(2): 431-442 (2008). doi:10.1017/S1074070800023725.

Dang, D. M. Agricultural insurance for Vietnamese coffee trees: Issues and analyze the necessity to apply agriculture insurance. Int. J. Econ. Com. and Mgt., 3(4): 1-14 (2015). 
Dasgupta, S., B. Laplante, C., Meisner, D., Wheeler, and J. Yan. The impact of sea level rise on developing countries, a comparative analysis. World Bank Policy Research Working Paper 4136. (2007).

De Bock, O., \& W. Gelade. The demand for micro insurance: A literature review. ILO Microinsurance Innovation Facility Research Paper (26) (2012).

Dercon, S., J. W. Gunning, A. Zeitlin, C. Cerrone, \& S. Lombardin. Health insurance participation: Experimental evidence from Kenya. ILO Micro insurance Innovation Facility Research Paper 10 (2012).

Du, X., H. Feng, and D. A. Hennessy. Rationality of choices in subsidized crop insurance markets. Am. J. Agric. Econ., 99: 732-756. (2017).

Duncan, J., and R. J. Myers. Crop insurance under catastrophic risk. Am. J. Agric. Econ., 82:842-855 (2000).

Epetimehin, F. M. Agricultural insurance in Nigeria and the economic impact: A review Int. J. Acad. Res. Bus. Soc. Sci., 1(3): (2011).

FAO. Guidelines to meet insurance and other risk management needs in developing aquaculture in Asia. FAO Fisheries Technical Paper 496. Rome: FAO (2007a).

FAO. Livestock and aquaculture insurance in developing countries. FAO Agricultural Services Bulletin 164. Rome: Food and Agriculture Organization of the United Nations. Office for Asia and the Pacific Bangkok (2007b).

FAO. Agricultural insurance in Asia and the Pacific region. Rap publication 2011/12; Regional (2011).

FAO. Workshop on development of aquaculture insurance system for small-scale farmers. Fisheries and Aquaculture Report No. 1177 FIAA/R1177 (En) Bangkok, Thailand, 20-21 September (2016).

Giesbert, L., S. Steiner, \& M. Bendig, Participation in micro life insurance and the use of other financial services in Ghana. J. Risk Insur., 78(1): 7-35 (2011).

Giné, X., R. Townsend, and J. Vickery. Patterns of rainfall insurance participation in rural India. World Bank Econ. Rev., 22(3): 539 (2008).

GlobalAgRisk. Designing Agricultural Index Insurance in Developing Countries: A GlobalAgRisk Market Development Model Handbook for Policy and Decision Makers. Lexington, KY: GlobalAgRisk. 142. Available from http://globalagrisk. com. (2009).

Goodwin, B. K. Agricultural reinsurance issues. AAEA Crop Insurance and The Farm Bill Symposium Louisville, Kentucky (2013).

Hadnes, M., and K. Czura. Evaluation of governmental pilot program on aquaculture insurance in $\mathrm{Ca}$ Mau Province for the period of 2011 till 2013. Ho Chi Minh City, Viet Nam: Integrated Coastal Management Programme (ICMP) (2014).

Hardaker, J. B., R. B. M. Huirne, and J. R. Anderson. Coping with Risk in Agriculture. New York: CABI International (1997).

Hawes, K. An introduction to aquaculture insurance. World. Fish. Aquacult., http://www.worldfishing.net/ news101/financeinsurance/an-introduction-to-aquacultureinsurance (2014).

Hazell. P., L. M. Bsssoco, and G. Arcia. A Model for Evaluating Farmers Demand for Insurance: Applications in Mexico and Panama. In: Crop Insurance for Agricultural Development: Issues and Experience (Hazell,
P. B. R., C. Pomareda, and A. Valdes, Eds.). Baltimore: The Johns Hopkins University Press (1986).

Hien, A. Agriculture insurance in Viet Nam and issues. E-J. Vietnam Communist Party. Available from http:// dangcongsan.vn/CPV/Modules/News/NewsDetail.aspx? co_id=30066\&cn_id=481778 (in Vietnamese) (2011).

Hill, R. V., and A. Viceisza. A field experiment on the impact of weather shocks and insurance on risky investment. Exp. Eco., 15(2): 341-371 (2012).

Hoang, H. T., and D. P. Khoi. Sustainable agricultural insurance: Theory and practice in implementation of the pilot program for agricultural insurance in Vietnam. J. Econ. Dev., 218: 48-55 (in Vietnamese) (2015).

IGES (Institute of Global Environmental Strategies). Promoting Risk Financing in the Asia Pacific Region: Lessons from Agriculture Insurance in Malaysia, Philippines and Viet Nam. Kanagawa, Japan: Asia Pacific Adaptation Network (APAN), 37 (2013).

IMUA Loss Control \& Claims Committee. Aquaculture: An overview of exposures: Underwriting concerns. Available from http://www.imua.org/Files/reports/Aquaculture_\%20 An\%20Overview\%20of\%20Exposures,\%20Loss\%20Prevention \%20and\%20Underwriting\%20Concerns.html (2008).

Johnson, E. J., J. Hershey, J. Meszaros, \& H. Kunreuther. Framing, probability distortions and insurance decisions. J. Risk. Uncert., 7(1): 35-51 (1993).

Just, R. E., L. Calvin, and J. Quiggin. Adverse selection in crop insurance: Actuarial and asymmetric information incentives. Am. J. Agric. Econ., 81: 834-49 (1999).

Khadka, N. S. Climate change: Mekong delta heads for troubled waters. Science Environment (2015).

Khoi, D. K., D. H. Thiep, N. T Hue, T. V. Tinh, and P. D. Tinh. A Study on Lessons Learned from the National Agriculture Pilot Program in Vietnam; Asian Climate Resilience, Hanoi, Vietnam (2017).

Kolstad, J. T., and A. E. Kowalski. Mandate-based health reform and the labor market: Evidence from the Massachusetts reform. J. Health Econ. 47: 81-106 (2016).

Kouame, E. B. H., and N. Komenan. Risk preference and demand for insurance under price uncertainty: An experimental approach for cocoa farmers in Cote d'Ivoire. Micro-ins. Inno. Fac., Research paper No. 13 (2012).

Kunreuther, H., and M. Pauly. Role of deliberative thinking and emotions in insurance decision making: An experimental study. Technical report, Working Paper 2014-03. RiskManagement and Decision Processes Center, Philadelphia, PA: Wharton School, University of Pennsylvania (2014).

Loc, V. T. T. Assessment of Agri-product value chains in the Mekong Delta: Problems and solutions. Can. Tho Univ. J. Sci., 2: 100-111 (2016).

Lutz, G. C. 'Vietnam pangasius industry still facing difficult times'. Aquaculture Magazine, February-March (2015).

Macedo, L. The Role of the Underwriter in Insurance; Primer Series on Insurance Issue 8, World Bank (2009).

Mahul, O., and C. J. Stutley. Government Support to Agricultural Insurance Challenges and Options for Developing Countries. Washington, D.C.: World Bank (2010)

Makki, S. S., and A. Somwaru. Asymmetric Information in the Market for Yield and Revenue Insurance Products. Washington, D.C.: Economic Research Service, U.S. 
Department of Agriculture. Technical Bulletin No. 1892 (2001).

Mc Intosh, D. Aquaculture Risk Management, Delaware State University, NRAC Publication No. 107-2008, Animal Science Building College Park, MD: University of Maryland. (2003)

MIA (Micro Insurance Academy). Supply and demand side study including product development and subsidies. Study report for the project on innovative financing for building community resilience to climate change in coastal Viet Nam submitted to the Netherlands Development Organization (SNV) Viet Nam. New Delhi, The Micro Insurance Academy, 12 January 2012, pp. 51 (2012).

Miller, J. C., J. E. Lee, T. R. Hanson, and K. H. Coble. 2002. 2002 National Risk Management for Aquaculture Workshop summary report. Mississippi State University Department of Agricultural Economics Information Report 2002-023. National Risk Management Feasibility Program for Aquaculture (PDF Download Available). Available from https://www.researchgate.net/publication/ 237708147_National_Risk_Management_Feasibility_ Program_for_Aquaculture_-_Examining_the_Feasibility_of_ Aquaculture_Insurance (2013).

Ministry of Finance and Provincial Steering Committees. Reports of the Ministry of Finance and Provincial People's Committees on the implementation of the National Agriculture Insurance Pilot Program in Vietnam (in Vietnamese) (2014).

Mishra, P. K. Agricultural Risk, Insurance and Income. Arabury, Vermont: Ashgate Publishing Company (1996).

MOF. Document for the training workshop on circular 121/ 2011/TT-BTC, 17 August 2011 (2011a).

MOF. Circular No.121/2011/TT-BTC dated 17 August 2011 of the Ministry of Finance on guiding the participation in the insurance program; GOV, Vietnam (2011b).

MOF. Decision No.315/QD-TTg on pilot implementation of agriculture insurance in the period 2011-2013; GOV, Vietnam (2011c).

MOF. Decision 2174/QD-BTC, Decision 2175/QD-BTC and Decision 2176/QD-BTC allowing Bao Viet, Bao Minh and VINARE to participate in the pilot program (2011d).

MOF. Report on the implementation results of the agriculture insurance pilot program, pp. 17 in Vietnamese (2014).

Nelson, C. H., and E. T. Loehman. Further Toward a Theory of Agricultural Insurance. Am. J. Agric. Econ. 69: 523-531 (1987).

Nguyen, C. T. A., and C. M. Jolly. Macro-economic and product challenges facing the Vietnamese pangasius industry. Rev. Fish. Sci. Aquacult. 26(2): 183-194. Available from https://doi.org/10.1080/23308249.2017.1379948 (2017).

Nguyen, T. A. K., and Pongthanapanich, T. Aquaculture insurance in Vietnam: Experience from a pilot programme. FAO Fisheries and Aquaculture circular No. 1133 (2016).

OECD. The Economics of Adapting Fisheries to Climate Change. Busan, Korea: OECD Publishing. Available from http://dx.doi.org/10.1787/9789264090415-en (2010).

Pomareda, C. An evaluation of the impact of credit insurance on bank performance in Panama. In: Crop Insurance for Agricultural Development: Issues and Experience (Hazell, P., Pomareda, C., and Valdes, A.,
Eds.). Batimore and London: The Johns Hopkins University Press (1986).

Pongthanapanich, T., K. A. T Nguyen, and Y. Xinhua. Insuring Small-Scale Farms Adds Resilience to the Aquaculture Value Chain. Bangkok, Thailand: FAO, Globefish (2016).

Power, M. The Risk Management of Everything: Rethinking the Politics of Uncertainty. London, UK: Demos (2004).

Prime Minister. Decision 09/QD-TTg Dated 30 January 2011 of the Prime Minister on Applying for Poor Households. Vietnam: GOV (2011).

Prime Minister. Changing the Decision to 90 Percent Poor Households (Decision No. 358 Dated 27 February). Vietnam: GOV (2013).

Raju, S. S., and R. Chand. Agricultural Insurance in India Problems and Prospects. New Delhi: National Centre for Agricultural Economics and Policy Research (Indian Council of Agricultural Research (2008).

Reddy, A. A. Agricultural insurance in India-A perspective; $6^{\text {th }}$ Global Conference of Actuaries, February 18-19, New Delhi (2004).

Rogers, B. Agricultural re/insurance in Vietnam; the Swiss Re Centre for Global Dialogue. Available from file:///D:/ Agricultural\%20re_insurance\%20in\%20Vietnam\%20_\%20 Swiss\%20Re\%20Institute.html (2013).

Roberts, R. A. J. Insurance of crops in developing countries, FAO Agricultural Services Bulletin 159, Rome: FAO; pp. 1-87 (2005).

Roberts, R. A. J. Livestock and Aquaculture Insurance in Developing Countries: A Brief Overview. Rome: Food and Agriculture Organization of the United Nations, pp. 65 (2007).

Secretan, P. A. D. The Availability of Aquaculture Crop (Stock Mortality) Insurance. Lewes, East Sussex: Aquacult. Underwriting. Manage. Serv., (AUMS). Available from file:///D:/Aquaculture\%20insurance\%20Sec\%20MortalityIns urance.pdf (2003).

Shaik, S., Coble, K. H., Miller, J. C., \& Hanson, T. R. Aquaculture Insurance: Issues, Policy Designs, and Potential Research. Department of Agricultural Economics Information Report 2003-001. Starkville, MI: Mississippi State University (2003).

Swiss Re. Understanding reinsurance. Zurich: Swiss Reinsurance Company (2004).

Thang, T. C. Agricultural policies in Vietnam, Institute of Policy and Strategy for Agriculture and Rural Development, Vietnam. Available from E:\Agricultural insurance policies in Vietnam_php.mhtTipparat (2014)

Thieu, D. H. T., and Van T. L. Agricultural insurance market development the role of Vietnam Government. Int. J. Econ. Commer. Manage., Available from http://ijecm.co. uk/ISSN 23480386 (2014).

van Anrooy, R., P.A.D. Secretan, Y. Lou, R. Roberts, M. Upare. Review of the current state of world aquaculture insurance. FAO Fisheries Technical Paper. No. 493. Rome: FAO, pp. 92 (2006).

VASEP Vietnam Association of Seafood Exporters and Producers. '2016: Vietnam pangasius exports to EU may rebound'. Available from http://seafood.vasep.com.vn/ seafood/51_11141/2016-vietnam-pangasius-exports-to-eumay-rebound.htm (2016). 
Velandia, M., R. M. Rejesus, T. O. Knight, and B. J. Sherrick. Factors affecting farmers' utilization of agricultural risk management tools: The case of crop insurance, forward contracting, and spreading sales. J. Agric. Appl. Econ. 41(1): 107-123 (2009).

Walton, W., and J. Gallons, Marine extension bulletin: Important changes to the federal crop insurance program for quahog farmers. Available from http://www.whoi.edu/seagrant/educ ation/bulletins/Cropinsurance.pdf on June 20, (2005).

Warner, K., N. Ranger, S. Surminski, M. Arnold, J. Linnerooth-Bayer, E. Michel-Kerjan, P. Kovaks, and C. Herweijer. Adaptation to Climate Change: Linking Disaster Risk Reduction and Insurance. Geneva, Switzerland: United Nations International Strategy for Disaster Reduction Secretariat (UNISDR) (2009).

World Bank Group. Introduction to Agricultural Insurance and Risk Management; Manual 1.Washington, D.C.: International Finance Corporation (2014).

World Bank. Agricultural Insurance Feasibility Study; Kazakhstan; Agriculture and Rural Development Unit
Sustainable Development Department Europe and Central Asia Region (2011).

World Bank. Weathering the Storm: Options for Disaster Risk Financing in VietNam. Global Facility for Disaster Reduction and Recovery (GFDRR). Washington, D.C.: The World Bank, pp. 136. Available from http://reliefweb.int/ sites/reliefweb.int/files/resources/61571C422DB58ADF492 57712001D20C5-Full_Report.pdf (2010).

World Bank. The Agricultural Insurance-A Risk Management Tool. Romania: World Bank. Available from http://www.worldbank.org/en/news/speech/2008/10/14/theagricultural-insurance-a-risk-management-tool (2008).

World Bank. Agricultural and Rural Development Department. Managing Agricultural Production Risk. Innovations in Developing Countries. Washington, DC (2005).

Zhai, F., and J. Zhuang. Agricultural impact of climate change: A general equilibrium analysis with special reference to Southeast Asia. Asian Development Institute Working Paper 131. Manila: Asian Development Bank (2009). 